\title{
KINERJA BENIH LELE YANG DIBERI PAKAN TAMBAHAN SERBUK SPIRULINA
}

\author{
Ria Putri Kusumaning Ayu ${ }^{1}$ dan Pungky Slamet Wisnu Kusuma ${ }^{2}$ \\ ${ }^{1}$ Alumni Prodi Biologi, FMIPA, Universitas PGRI AdiBuana Surabaya \\ ${ }^{2}$ Staf Pengajar Prodi S1 Biologi, FMIPA, Universitas PGRI AdiBuana Surabaya \\ ${ }^{1}$ Author \\ Auee.coddy@gmail.com \\ ${ }^{2}$ Corresponding Author \\ slametswk@yahoo.com
}

\begin{abstract}
Feed is an important element that can support the growth and survival of fish. Feed that is suitable for nutrition and high digestion value can support maximum growth in cultivated fish. S. plastensisis a type of cyanobacteria that contains nutrients such as proteins, essential fatty acids, minerals, vitamins, and antioxidants. This study aims to determine the effect of the addition S. plastensis powder in feed on the growth, SR and FCR of catfish seeds. Experimental study with 5 treatments and 5 replications, treatment A (S. plastensis powder $0 \mathrm{~g} / \mathrm{kg}$ feed), treatment B (S. plastensis powder $2 \mathrm{~g} / \mathrm{kg}$ feed), C treatment $(S$. plastensis powder $3 \mathrm{~g} / \mathrm{kg}$ feed) and treatment D (S. plastensis powder $4 \mathrm{~g} / \mathrm{kg}$ feed), and $\mathrm{E}$ treatment ( $S$. plastensis powder $6 \mathrm{~g} / \mathrm{kg}$ feed). Feed is given twice, every morning and evening for 35 days. The results showed the addition of $S$. plastensis powder to the feed could have a significant effect $(\mathrm{P}<0.05)$ on increasing growth, SR and FCR on catfish seeds.
\end{abstract}

Keywords: Spirulina platensis, catfish seeds, growth, SR and FCR

PENDAHULUAN

Departemen Kelautan dan Perikanan (2010), menetapkan ikan lele sebagai salah satu hasil perikanan budidaya yang menempati urutan teratas dalam jumlah produksi yang dihasilkan. Selama ini ikan lele menyumbang lebih dari $10 \%$ produksi perikanan budidaya nasional dengan tingkat pertumbuhan mencapai 17 hingga $18 \%$. Wijaya et al., 2014, menyatakan bahwa tingginya angka konsumsi dalam negeri dan terbukannya pangsa pasar ekspor, memastikan komoditas ikan air tawar ini menjadi penyumbang devisa negara yang sangat menjanjikan.

Hal ini menyebabkan permintaan ikan selalu meningkat dari waktu ke waktu seiring dengan pertambahan jumlah penduduk (Muchlisin et al., 2003).

Pakan merupakan salah satu unsur penting dalam kegiatan budidaya yang menunjang pertumbuhan dan kelangsungan hidup ikan budidaya. Pakan pada kegiatan budidaya umumnya adalah 
pakan komersial yang menghabiskan sekitar $60-70 \%$ dari total biaya produksi yang dikeluarkan. Disisi lain, budidaya dapat menimbulkan berbagai dampak negatif, salah satunya adalah penyakit. Hingga saat ini bahan yang sering digunakan untuk menanggulangi penyakit pada ikan budidaya adalah pengobatan dengan zat kimia atau antibiotik. Upaya lain yang dilakukan untuk mengobati penyakit ini adalah dengan menggunakan bahan alami. Salah satu bahan alami yang mengandung senyawa antibakteri adalah Spirulina.

S. platensis sebagai sumber yang sangat kaya protein, vitamin, dan mineral. Kandungan protein pada Spirulina sp. Berkisar antara $60-70 \%$ dari berat kering. Mengandung provitamin A yang tinggi, sumber $\beta$-karoten yang kaya vitamin B12 dan digunakan dalam pengobatan anemia, kandungan lipid sekitar 4-7\%, serta karbohidrat sekitar 13,6 \% (Carrieri et al., 2010). Spirulina juga mengandung nutrisi yang tinggi seperti Gamma Linoleic Acid (GLA) dan enzym pencernaan (Demir \& Tukel, 2010). Salah satu jenis spirulina sp yaitu S.platensis.

Sprulina platensis dapat dimanfaatkan sebagai suplemen bahan pakan, makanan dan pengobatan (Suzanna et al., 2007). Spirulina platensis selain berperan merangsang pertumbuhan juga berperan sebagai imunostimulan karena dapat meningkatkan daya tahan tubuh ikan (Utomo et al., 2012).

\section{METODE PENELITIAN}

Jenis penelitian eksperimen menggunakan Rancangan Acak Lengkap (RAL) untuk mengetahui pengaruh pemberian bubuk $S$. platensis dalam pakan komersial terhadap pertumbuhan, survival rate serta Feed Conversion Rasio pada benih ikan lele. Penelitian ini menggunakan 5 perlakuan yaitu 0 $\mathrm{g} / \mathrm{kg}$ pakan, $2 \mathrm{~g} / \mathrm{kg}$ pakan, $3 \mathrm{~g} / \mathrm{kg}$ pakan, $4 \mathrm{~g} / \mathrm{kg}$ pakan dan $6 \mathrm{~g} / \mathrm{kg}$, diulang sebanyak 5 kali.

Data diperoleh dengan tekhnik pengumpulan data eksperimental, yang diambil dari data primer yaitu data yang diambil setelah melakukan penelitian. Data yang diperoleh dianalisa dengan menggunakan analisa varian (ANOVA) yang di identifikasi dengan nilai signifikan grup $(\mathrm{P}<0,05)$ kemudian dilanjutkan dengan uji Duncan untuk mengetahui perbedaannya (SPSS 20).

\section{HASIL PENELITIAN Hasil Analisa Proksimat}

Data hasil Analisa proksimat pada pakan ikan lele setelah ditambah $S$. platensis dapat dilihat pada table 1 dibawah ini. 
Tabel 1. Hasil analisa proksimat pakan ikan lele yang ditambah serbuk $S$. platensis

\begin{tabular}{|c|c|c|c|c|c|}
\hline & $\begin{array}{c}\text { Protein } \\
\mathrm{g} / \mathrm{kg}\end{array}$ & $\begin{array}{c}\text { Lemak } \\
\mathrm{g} / \mathrm{kg}\end{array}$ & $\begin{array}{c}\text { Air } \\
\mathrm{g} / \mathrm{kg}\end{array}$ & $\begin{array}{c}\mathrm{Abu} \\
\mathrm{g} / \mathrm{kg}\end{array}$ & $\begin{array}{c}\mathrm{KH} \\
\mathrm{g} / \mathrm{kg}\end{array}$ \\
\hline S. plastensis 0 g/kg pakan & 1,45 & 4,21 & 7,82 & 11,87 & 74,65 \\
\hline S. plastensis 2 g/kg pakan & 2,38 & 4,01 & 9,23 & 11,76 & 72,62 \\
\hline S. plastensis 3 g/kg pakan & 4,68 & 4,00 & 10,12 & 11,56 & 69,44 \\
\hline S. plastensis $4 \mathrm{~g} / \mathrm{kg}$ pakan & 6,33 & 4,05 & 9,45 & 11,69 & 68,48 \\
\hline S. plastensis $6 \mathrm{~g} / \mathrm{kg}$ pakan & 6,48 & 4,51 & 10,75 & 11,73 & 66,53 \\
\hline
\end{tabular}

\section{Laju Pertumbuhan}

\section{Pertambahan Bobot}

Data laju pertambahan

bobot benih ikan didapatkan dengan cara mengukur dan mencatat perubahan bobot ikan setiap 7 hari sekali selama 35 hari, adalah sebagai berikut:

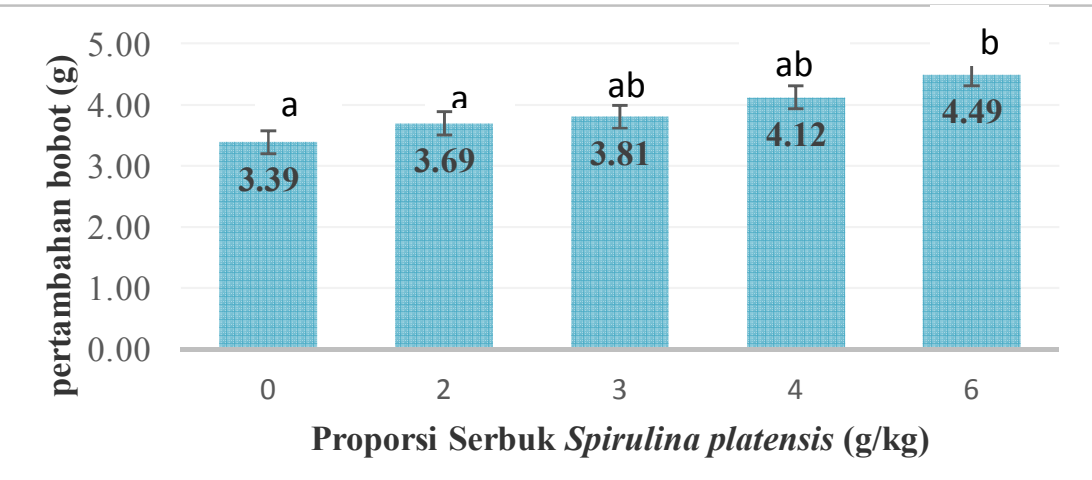

Gambar 1. Pertambahan bobot benih ikan lele yang diberi pakan tambahan serbuk $S$. platensis, angka yang diberi notasi berbeda signifikan $(\mathrm{P}<0,05)$.

Hasil

penelitian memperlihatkan bahwa penambahan serbuk S. plastensispada pakan berpengaruh signifikan terhadap pertambahan bobot benih lele.Gambar 1 menunjukkan bahwa perbedaan bobot benih lele yang diberi pakan tambahan $0 \mathrm{~g} / \mathrm{kg}$ pakan signifikan $(\mathrm{P}<0,05)$ lebih rendah apabila dibandingkan dengan $6 \mathrm{~g} / \mathrm{kg}$ pakan, namun tidak berbeda signifikan $(\mathrm{P}>0,05)$ dengan penambahan serbuk $S$. plastensisdengan pemberian kadar 2 $\mathrm{g} / \mathrm{kg}$ pakan, $3 \mathrm{~g} / \mathrm{kg}$ pakan, dan 4 $\mathrm{g} / \mathrm{kg}$ pakan. 
Kadar $2 \mathrm{~g} / \mathrm{kg}$ pakan tidak berbeda signifikan $(\mathrm{P}>0,05)$ terhadap pemberian $S$. plastensis sebanyak $0 \mathrm{~g} / \mathrm{kg}$ pakan, $3 \mathrm{~g} / \mathrm{kg}$ pakan, dan $4 \mathrm{~g} / \mathrm{kg}$ pakan, tetapi berbeda signifikan $(\mathrm{P}<0,05)$ terhadap penambahan kadar $6 \mathrm{~g} / \mathrm{kg}$ pakan. Kadar $3 \mathrm{~g} / \mathrm{kg}$ pakan tidak berbeda signifikan $(\mathrm{P}>0,05)$ terhadap pemberian $S$. plastensissebanyak $0 \mathrm{~g} / \mathrm{kg}$ pakan, 2 $\mathrm{g} / \mathrm{kg}$ pakan dan $4 \mathrm{~g} / \mathrm{kg}$ pakan, tetapi berbeda signifikan $(\mathrm{P}<0,05)$ terhadap penambahan kadar $6 \mathrm{~g} / \mathrm{kg}$ pakan. Kadar $4 \mathrm{~g} / \mathrm{kg}$ pakan tidak berbeda signifikan $(\mathrm{P}>0,05)$ terhadap pemberian $S$. plastensis sebanyak $0 \mathrm{~g} / \mathrm{kg}$ pakan, $2 \mathrm{~g} / \mathrm{kg}$ pakan, dan $3 \mathrm{~g} / \mathrm{kg}$ pakan, tetapi berbeda signifikan $(\mathrm{P}<0,05)$ terhadap penambahan kadar $6 \mathrm{~g} / \mathrm{kg}$ pakan dan kadar $6 \mathrm{~g} / \mathrm{kg}$ pakan berbeda signifikan $(\mathrm{P}<0,05)$ terhadap pemberian $S$. plastensis sebanyak $0 \mathrm{~g} / \mathrm{kg}$ pakan, $2 \mathrm{~g} / \mathrm{kg}$ pakan, $3 \mathrm{~g} / \mathrm{kg}$ pakan dan $4 \mathrm{~g} / \mathrm{kg}$ pakan.

\section{Pertambahan Panjang}

Data laju pertambahan panjang benih ikan lele didapatkan dengan cara mengukur dan mencatat perubahan panjang benih ikan setiap 7 hari sekali selama 35 hari, adalah sebagai berikut:

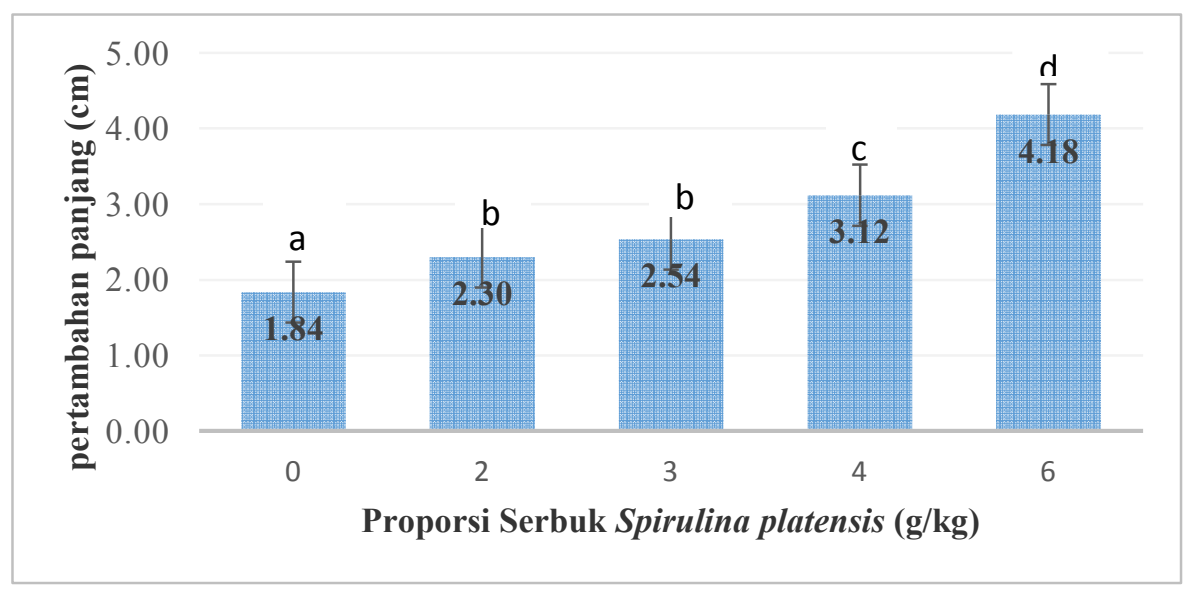

Gambar 2. Pertambahan panjang benih ikan lele yang diberi pakan tambahan serbuk Spirulina platensis, angka yang diberi notasi berbeda signifikan $(\mathrm{P}<0,05)$

Hasil

penelitian memperlihatkan bahwa penambahan serbuk $S$. platensis pada pakan berpengaruh signifikan terhadap pertambahan panjang benih lele.Gambar 2 menunjukkan bahwa perbedaan panjang benih lele yang diberi pakan tambahan $0 \mathrm{~g} / \mathrm{kg}$ pakan 
signifikan $(\mathrm{P}<0,05)$ lebih rendah bila dibandingkan dengan $6 \mathrm{~g} / \mathrm{kg}$ pakan, $4 \mathrm{~g} / \mathrm{kg}$ pakan, $3 \mathrm{~g} / \mathrm{kg}$ pakan dan $2 \mathrm{~g} / \mathrm{kg}$ pakan.

Penambahan $2 \mathrm{~g} / \mathrm{kg}$ pakan tidak memberikan hasil yang berbeda signifikan $(\mathrm{P}>0,05)$ bila dibandingkan dengan $3 \mathrm{~g} / \mathrm{kg}$ pakan, tetapi berbeda signifikan $(\mathrm{P}<0,05)$ bila dibandingkan dengan penambahan kadar sebesar $0 \mathrm{~g} / \mathrm{kg}$ pakan, $4 \mathrm{~g} / \mathrm{kg}$ pakan dan $6 \mathrm{~g} / \mathrm{kg}$ pakan. Penambahan $3 \mathrm{~g} / \mathrm{kg}$ pakan tidak memberikan hasil yang berbeda signifikan $(\mathrm{P}>0,05)$ bila dibandingkan dengan $2 \mathrm{~g} / \mathrm{kg}$ pakan, tetapi berbeda signifikan $(\mathrm{P}<0,05)$ bila dibandingkan dengan $0 \mathrm{~g} / \mathrm{kg}$ pakan, $4 \mathrm{~g} / \mathrm{kg}$ pakan dan $6 \mathrm{~g} / \mathrm{kg}$ pakan. Penambahan $4 \mathrm{~g} / \mathrm{kg}$ pakan memberikan hasil yang berbeda signifikan $(\mathrm{P}<0,05)$ bila dibandingkan dengan $0 \mathrm{~g} / \mathrm{kg}$ pakan, $2 \mathrm{~g} / \mathrm{kg}$ pakan, $3 \mathrm{~g} / \mathrm{kg}$ pakan dan 6 $\mathrm{g} / \mathrm{kg}$ pakan. Penambahan $6 \mathrm{~g} / \mathrm{kg}$ pakan memberikan hasil yang berbeda signifikan $(\mathrm{P}<0,05)$ bila dibandingkan dengan $0 \mathrm{~g} / \mathrm{kg}$ pakan, $2 \mathrm{~g} / \mathrm{kg}$ pakan, $3 \mathrm{~g} / \mathrm{kg}$ pakan dan 4 $\mathrm{g} / \mathrm{kg}$.

\section{Tingkat Kelangsungan Hidup} (SR) Benih Lele

Data nilai SR benih lele dihitung dari presentase jumlah ikan yang hidup di akhir masa pemeliharaan dibandingkan dengan jumlah awal pada saat penebaran. SR benih ikan lele yang diberi pakan tambahan serbuk Spirulina platensis dapat dilihat pada diagram batang dibawah ini.

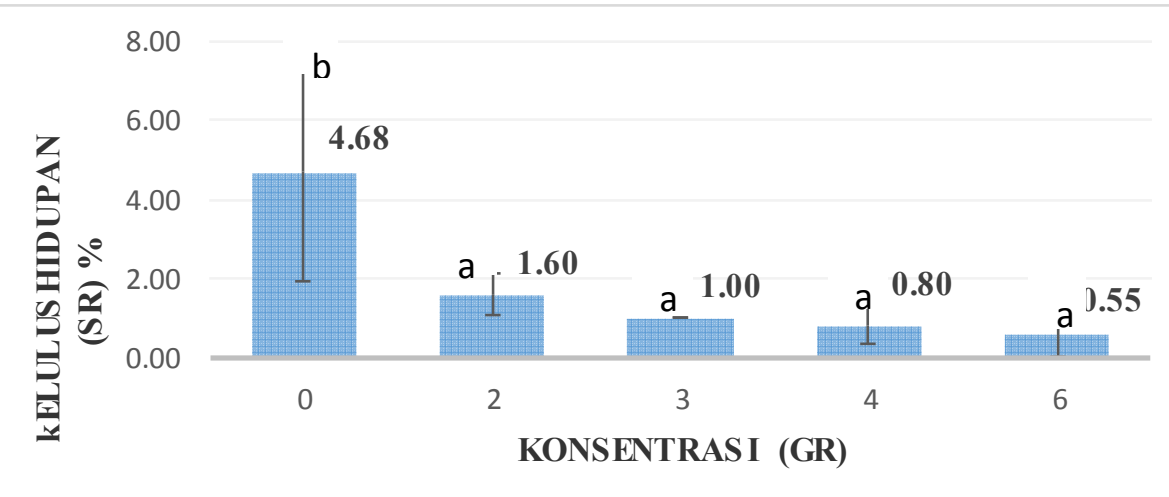

Gambar 3. SR benih ikan lele yang diberi pakan tambahan serbuk $S$. platensis, angka yang diberi notasi berbeda signifikan (P $<0,05)$

Hasil memperlihatkan bahwa penambahan serbuk $S$. platensis pada pakan berpengaruh signifikan terhadap SR benih ikan lele. Gambar 3 menunjukkan bahwa SR benih ikan lele yang diberi pakan tambahan 0 $\mathrm{g} / \mathrm{kg}$ pakan berbeda signifikan $(\mathrm{P}<$ 
0,05) bila dibandingkan dengan kadar penambahan serbuk $S$. platensis sebesar $2 \mathrm{~g} / \mathrm{kg}, 3 \mathrm{~g} / \mathrm{kg}, 4$ $\mathrm{g} / \mathrm{kg}$ dan $6 \mathrm{~g} / \mathrm{kg}$.

Penambahan $2 \mathrm{~g} / \mathrm{kg}$ pakan tidak berbeda signifikan $(\mathrm{P}>0,05)$ bila dibandingkan dengan kadar 3 $\mathrm{g} / \mathrm{kg}$ pakan, $4 \mathrm{~g} / \mathrm{kg}$ pakan, dan 6 $\mathrm{g} / \mathrm{kg}$ pakan, tetapi berbeda signifikan $(\mathrm{P}<0,05)$ dengan kadar 0 $\mathrm{g} / \mathrm{kg}$ pakan. Penambahan $3 \mathrm{~g} / \mathrm{kg}$ pakan tidak berbeda signifikan $(\mathrm{P}>$ $0,05)$ bila dibandingkan dengan kadar $2 \mathrm{~g} / \mathrm{kg}$ pakan, $4 \mathrm{~g} / \mathrm{kg}$ pakan, dan $6 \mathrm{~g} / \mathrm{kg}$ pakan, tetapi berbeda signifikan $(\mathrm{P}<0,05)$ dengan kadar 0 $\mathrm{g} / \mathrm{kg}$ pakan. Penambahan $4 \mathrm{~g} / \mathrm{kg}$ pakan tidak berbeda signifikan $(\mathrm{P}>$ $0,05)$ bila dibandingkan dengan kadar $2 \mathrm{~g} / \mathrm{kg}$ pakan, $3 \mathrm{~g} / \mathrm{kg}$ pakan, dan $6 \mathrm{~g} / \mathrm{kg}$ pakan, tetapi berbeda signifikan $\quad(\mathrm{P}<0,05) \quad$ bila dibandingkan dengan kadar $0 \mathrm{~g} / \mathrm{kg}$ pakan. Penambahan $6 \mathrm{~g} / \mathrm{kg}$ pakan tidak berbeda signifikan $(P>0,05)$ bila dibandingkan dengan kadar 2 $\mathrm{g} / \mathrm{kg}$ pakan, $3 \mathrm{~g} / \mathrm{kg}$ pakan, dan 4 $\mathrm{g} / \mathrm{kg}$ pakan, tetapi berbeda signifikan $\quad(\mathrm{P}<0,05) \quad$ bila dibandingkan dengan kadar $0 \mathrm{~g} / \mathrm{kg}$ pakan.

\section{Feed Conversi Rasio}

FCR (Feed Conversion Rasio) merupakan parameter yang digunakan untuk mengetahui tingkat efisiensi penggunaan pakan oleh benih ikan lele untuk membentuk daging. Semakin kecil FCR maka semakin tinggi efisiensi penggunaan pakan. Hasil FCR benih ikan lele yang diberi pakan tambahan $S$. platensis dapat dilihat pada diagram batang dibawah ini.

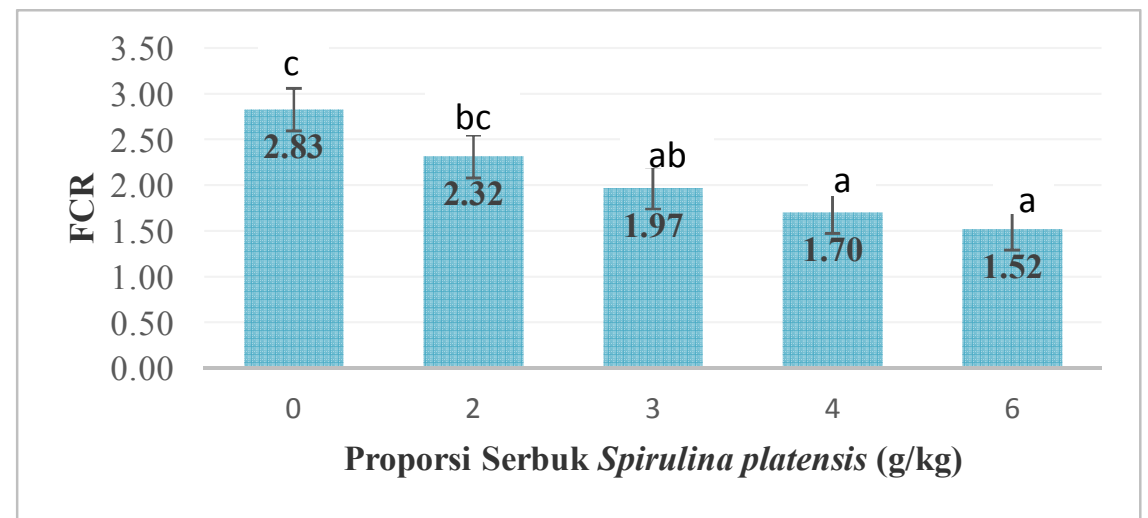

Gambar 4. FCR benih ikan lele yang diberi pakan tambahan serbuk S. platensis, angka yang diberi notasi berbeda signifikan $(\mathrm{P}<0,05)$.

Hasil

penelitian

serbuk Spirulina platensis pada memperlihatkan bahwa penambahan pakan berpengaruh signifikan 
terhadap FCR benih ikan lele. Gambar 4 menunjukkan FCR benih lele yang diberi pakan tambahan 0 $\mathrm{g} / \mathrm{kg}$ pakan berbeda signifikan $(\mathrm{P}<$ $0,05)$ bila dibandingkan dengan 3 $\mathrm{g} / \mathrm{kg}$ pakan, $4 \mathrm{~g} / \mathrm{kg}$ pakan dan $6 \mathrm{~g} / \mathrm{kg}$ pakan, tetapi tidak berbeda signifikan $(\mathrm{P}>0,05)$ dengan kadar 2 $\mathrm{g} / \mathrm{kg}$ pakan. dan $6 \mathrm{~g} / \mathrm{kg}$ pakan, tetapi tidak berbeda signifikan $(\mathrm{P}>0,05)$ dengan kadar $2 \mathrm{~g} / \mathrm{kg}$ pakan.

Penambahan kadar $2 \mathrm{~g} / \mathrm{kg}$ pakan tidak berbeda signifikan $(\mathrm{P}>$ $0,05)$ bila dibandingkan dengan kadar $0 \mathrm{~g} / \mathrm{kg}$ pakan, tetapi berbeda signifikan terhadap kadar $3 \mathrm{~g} / \mathrm{kg}$ pakan, $4 \mathrm{~g} / \mathrm{kg}$ pakan dan $6 \mathrm{~g} / \mathrm{kg}$ pakan. Penambahan kadar $3 \mathrm{~g} / \mathrm{kg}$ pakan tidak berbeda signifikan $(\mathrm{P}>$ $0,05)$ bila dibandingkan dengan kadar $4 \mathrm{~g} / \mathrm{kg}$ pakan dan $6 \mathrm{~g} / \mathrm{kg}$ pakan, tetapi berbeda signifikan ( $\mathrm{P}$ $<0,05)$ bila dibandingkan dengan kadar $0 \mathrm{~g} / \mathrm{kg}$ pakan dan $2 \mathrm{~g} / \mathrm{kg}$ pakan. Penambahan kadar $4 \mathrm{~g} / \mathrm{kg}$ pakan tidak berbeda signifikan $(\mathrm{P}>$ $0,05)$ bila dibandingkan dengan kadar $3 \mathrm{~g} / \mathrm{kg}$ pakan dan $6 \mathrm{~g} / \mathrm{kg}$ pakan, tetapi berbeda signifikan $(\mathrm{P}$ $<0,05)$ bila dibandingkan dengan kadar $0 \mathrm{~g} / \mathrm{kg}$ pakan dan $2 \mathrm{~g} / \mathrm{kg}$ pakan.

Penambahan kadar $6 \mathrm{~g} / \mathrm{kg}$ pakan tidak berbeda signifikan $(\mathrm{P}>$ $0,05)$ bila dibandingkan dengan kadar $3 \mathrm{~g} / \mathrm{kg}$ pakan dan $4 \mathrm{~g} / \mathrm{kg}$ pakan, tetapi berbeda signifikan ( $\mathrm{P}$ $<0,05)$ bila dibandingkan dengan kadar $0 \mathrm{~g} / \mathrm{kg}$ pakan dan $2 \mathrm{~g} / \mathrm{kg}$ pakan.

\section{PEMBAHASAN}

\section{Laju Pertumbuhan}

Hasil

penelitian

memperlihatkan bahwa penambahan serbuk S. platensis kedalam pakan dapat meningkatkan laju pertumbuhan benih lele. Salah satu faktor yang berpengaruh pada pertumbuhan ikan adalah ketersediaan pakan. Ikan membutuhkan nutrisi yang lengkap dalam pakan, baik berupa protein, lemak, karbohidrat, mineral dan vitamin, untuk menunjang pertumbuhannya. Jika salah satu nutrisi tersebut tidak terpenuhi maka pertumbuhan ikan akan terganggu (Halver, 2003).

Pakan komersil yang telah ditambahkan dengan serbuk $S$. platensis dengan dosis yang berbeda setelah dilakukan pengujian analisa proximat menunjukkan. Semakin tinggi dosis serbuk $S$. platensis yang ditambahkan, maka semakin tinggi pula kandungan protein yang ada dalam pakan tersebut.

Protein merupakan salah satu nutrisi yang berperan penting dalam faktor pertumbuhan pada ikan yang dibudidaya. Spirulina platensis juga mengandung vitamin dan mineral yang sangat penting untuk kesehatan tubuh ikan. Banyaknya kandungan pakan yang dihidrolisa menjadi molekul yang lebih sederhana dapat meningkatnya luas area penyerapan saluran cerna sehingga akan mempercepat penyerapan nutrisi dan dapat dimanfaatkan oleh tubuh ikan. 
Karbohidrat dibutuhkan ikan dalam jumlah yang besar sebagai sumber energi untuk pertumbuhan. Pengunaan karbohidrat untuk menggantikan protein dan lemak sebagai sumber energi dapat dimaksimalkan untuk mengurangi biaya pakan, karena sumber energi karbohidrat lebih ekonomis, dan mudah dicerna dan dimanfaatkan oleh ikan (Herry, 2008).

Meskipun karbohidrat tidak berpengaruh langsung terhadap pertumbuhan, tetapi keberadaan karbohidrat sebagai unsur penyedia energi termurah dalam pakan sangat dibutuhkan.

Ketiadaannya karbohidrat dalam komponen pakan akan memaksa protein untuk dirubah fungsinya dari zat pembangun menjadi penyedia energi. Pengalih fungsian ini akan membutuhkan energi yang besar sehingga mengakibatkan kadar buangan gas ammonia ikan akan meningkat.

Hasil hidrolisa karbohidrat menjadi glukosa kemudian diserap oleh saluran cerna dan akan digunakan sebagai sumber energi untuk aktifitas, metabolisme pokok dan pertumbuhan. Penggunaan karbohidrat sebagai sumber energi secara maksimal akan mengurangi penggunaan protein sebagai sumber energi. Sehingga, protein yang telah tercerna tersebut digunakan untuk pertumbuhan ikan uji menjadi meningkat dengan respon laju pertumbuhannya yang tinggi. Hal penelitian ini didukung oleh
Gusrina (2008) yang menyatakan bahwa energi berasal dari karbohidrat dapat menghasilkan protein sparing effect, sehingga mengurangi penggunaan protein sebagai sumber energi, dimana protein yang telah dihidrolisis menjadi asam amino akan segera digunakan untuk pertumbuhan dan pergantian jaringan yang rusak. Hal inilah yang diduga dapat meningkatkan laju pertumbuhan benih lele pada penelitian ini.

Spirulina platensis dapat digunakan sebagai bahan pengganti tepung ikan pada pakan ikan trout karena kandungan protein yang tinggi dan tidak mempunyai efek negatif terhadap kinerja ikan (Teimouri et al., 2013). Ini dikarenakan Spirulina platensis mengandung nilai nutrisi yang tinggi, seperti Gamma Linoleic acid (GLA) dan enzim pencernaan (Demir-Tukel, 2010), vitamin (terutama vitamin A dan B12) (Wang et al., 2007).

Spirulina platensis mengandungi protein sekitar 60$70 \%$ dan mineral (SaranrajSivasakthi, 2014), lemak essensial,vitamin, mineral dan pigmen (Ali-Saleh, 2012) dan itu semua dibutuhkan untuk pertumbuhan ikan. Penambahan serbuk S. platensis terbukti dapat meningkatkan bobot dan pertumbuhan panjang benih ikan lele. Hal ini diperkuat oleh Ahmadzade-Nia et al., (2011) yang menyatakan bahwa penambahan 
level yang berbeda $S$. platensis dalam tepung kedelai dapat meningkatkan penambahan bobot ikan trout pada semua perlakuan hasilnya lebih tinggi jika dibandingkan dengan kontrol. Dernekbasi et al.,(2010) juga melaporkan bahwa penambahan suplementasi $S$. platensis pada pakan dapat memberikan pertumbuhan yang baik, apabila dibandingkan dengan pakan komersil pada ikan guppy. Hal yang sama juga ditunjukkan oleh Hirahashi et al.,(2002) bahwa penambahan $S$. platensis pada pakan ikan dan udang dapat meningkatkan pertumbuhan dan survival rate.

Penambahan level pada $S$. platensis dalam penelitian ini terbukti dapat meningkatkan bobot dan pertumbuhan pada benih lele. Ini dikarenakan bahwa $S$. platensis dapat dicerna dengan baik oleh benih lele. Baresto (2001) menyatakan bahwa dinding sel $S$. platensis tidak mengandung selulosa. Dinding sel nya terdiri dari mukopolisakarida sehingga dapat dengan mudah diserap oleh enzim sekresi yang ada di pencernaan ikan.Selain itu, diduga karena adanya pengaruh immunostimulan pada $S$. platensis yang dapat meningkatkan ketahanan tubuh dari gangguan penyakit atau bakteri patogen, sehingga gangguan yang dapat menyebabkan ikan stress pada lingkungan dapat diminimalisasikan. Proses peningkatan pertumbuhan terjadi secara tidak langsung, peningkatan dibuktikan dari peran immunostimulan yang terkandung dalam S. platensis bekerja sehingga benih lele menjadi lebih kuat dari gangguan stress lingkungan dan penyakit, sehingga energi pemanfaatan untuk pertumbuhan lebih efisien dan sempurna apabila dibandingkan dengan pakan yang tanpa penambahan serbuk $S$. platensis (kontrol).

Selanjutnya, Nakono et al., (2003) menjelaskan bahwa kurangnya selulosa dari struktur seluler $S$. platensis membuatnya mudah dicerna, sehingga meningkatkan nafsu makan ikan, meningkatkan asupan pakan dan kecernaan nutrisi dan meningkatkan kesehatan ikan, meningkatkan kemampuan untuk melawan infeksi melalui pengurangan tingkat stres.

Hasil dari penelitian ini adalah laju pertumbuhan yang meliputi pertumbuhan bobot dan panjang benih yang paling tinggi dengan penambahan $S$. platensis sebesar $6 \mathrm{~g} / \mathrm{kg}$ pakan. Hal ini sejalan dengan penelitian yang telah dilakukan oleh Simanjuntak et al., (2018) yang menyatakan bahwa pemberian serbuk $S$. platensis kedalam pakan komersil sebanyak 6 $\mathrm{g} / \mathrm{kg}$ pakan dapat meningkatkan laju pertumbuhan bagi ikan gurami.

\section{Tingkat SR (survival rate) Benih} Ikan Lele

Tingkat kelangsungan hidup benih ikan lele pada pakan yang 
telah diberi tambahan serbuk $S$. plastensisdiperoleh hasil tertinggi yaitu pada konsentrasi $6 \mathrm{~g} / \mathrm{kg}$ pakan. Spirulina mengandung phytopigmen seperti phycobilin, phycocyanin, allophycocyanin dan xanthophylls yang berhubungan dengan aktifitas antioksidan (Barmejo et al., 2008). Hu C et al., (2008) menjelaskan bahwa karatenoid pada alga merupakan aktifitas antioksidan yang berguna untuk melindungi komponen seluler agar ikan tidak gampang stress. Selain itu, penelitian yang dilakukan oleh Hirahashi et al., (2002) menyatakan bahwa penambahan serbuk S. platensis terhadap ikan dan udang dapat meningkatkan nilai kelulushidupan serta pertumbuhan.

$$
\text { Kelangsungan hidup }
$$

dipengaruhi oleh berbagai faktor yakni kualitas dan kuantitas pakan, genetis dan kualitas bibit, kualitas air media pemeliharaan dan keberadaan agen penyakit (Yuniarti, 2006). Hasil dari penelitian (Gambar 3) menunjukkan bahwa jumlah pakan yang diberikan sudah cukup untuk mendukung kebutuhan pokok benih ikan lele tersebut, sebab pada tingkat kelangsungan hidup yang tinggi artinya pakan memberikan pengaruh yang positif terhadap pertumbuhan. Keadaan ini didukung oleh kualitas air selama penelitian yang cukup mendukung terhadap kehidupan ikan. Setiap tiga hari sekali dilakukan penyimpanan untuk membuang kotoran, sehingga menyebabkan kualitas air media tetap stabil dalam kisaran layak bagi pertumbuhan ikan.

Hal ini dibuktikan menurut Hermanto, (2000) yang menyatakan bahwa faktor genetis berupa bibit unggul saja tidak cukup untuk menghasilkan kualitas benih yang bermutu sehingga meningkatkan keberhasilan budidaya ikan pada tahap pembesaran. Faktor lain yang mempengaruhi kualitas benih ikan adalah pemberian pakan dan proses pemeliharaan yang terkontrol.

\section{FCR (Feed Conversi Rasio) Benih Ikan Lele}

FCR benih ikan lele pada pakan yang telah diberi tambahan serbuk $S$. plastensisdiperoleh hasil terbaik yaitu pada dosis $6 \mathrm{~g} / \mathrm{kg}$ pakan.Faktor yang mempengaruhi tinggi rendahnya efisiensi pakan adalah jenis dan jumlah sumber nutrisi dalam pakan yang diberikan pada ikan uji. Pada penelitian ini, hasil FCR mengindikasikan bahwa tingginya penambahan serbuk $S$. platensis pada pakan dapat menurunkan nilai FCR pakan. Nilai FCR pakan yang rendah berarti pakan yang diberikan itu lebih baik dan lebih efisien untuk pertumbuhan.

Nilai nutrisi serbuk $S$. plastensisjuga meningkat apabila konsentrasi yang digunakan juga meningkat. Hal ini sesuai dengan Palmegio et al., (2005) yang menyatakan bahwa pakan yang diberi tambahan serbuk $S$. platensis pada ikan Sturgeon (Acipenser 
baeri) mempunyai pertumbuhan yang lebih baik daripada kontrol, meningkatkan biomassa dan pertumbuhan, nilai FCR yang paling baik dan tingginya protein serta nilai efisiensi.

Hariyadi, et al., (2005) menyatakan bahwa semakin tinggi efisiensi pakan yang diketahui dari rendahnya nilai FCR, maka respon yang diberikan oleh ikan tersebut terhadap pakan semakin baik yang ditunjukkan dengan pertumbiuhan ikan yang semakin cepat dengan jumlah pakan yang dikonsumsi semakin sedikit.Selain itu, Simanjuntak et al., (2018) juga menyatakan bahwa nilai FCR pada dosis $6 \mathrm{~g} / \mathrm{kg}$ pakan pada pakan ikan dengan tambahan serbuk $S$. platensis yang diujikan kepada ikan gurami merupakan nilai FCR yang terbaik. Hal ini dikarenakan bahwa kandungan nutrisi yang terdapat dalam spirulina semakin bertambah jika level serbuk spirulina juga bertambah.

\section{KESIMPULAN}

Penambahan serbuk $S$. platensis pada pakan memberikan pengaruh yang signifikan terhadap laju pertumbuhan (pertambahan panjang dan bobot),meningkatkan kelangsungan hidup serta dapat menurunkan FCR benih ikan lele. Hasil yang paling baik untuk laju pertumbuhan (pertambahan panjang dan bobot), kelangsungan hidup serta FCR yaitu pada konsentrasi 6 $\mathrm{g} / \mathrm{kg}$ pakan.

\section{DAFTAR PUSTAKA}

Abd El-Baky, H., El Baz, F.K., dan El-Baroty, G.S. 2007. Enhancement of Antioksidant Production in $S$. plastensisUnder Oxidative Stress.American-Eurasian Journal of Scientific Research 2 (2): 170-9

Afrianto, E. dan Evi L. 2005. Pakan Ikan. Yogyakarta : Kanisius (Anggota IKAPI)

Ahmadzade-Nia, Y., Naser Adl, K., Hezave, S.G., Hejazi, M.S., Hassanpour, S., Chaichisemsari, M., \& Riyazi, S.R (2011). Effect of replacing different levels of Soybean meal with Spirulina on performance in Rainbow Trout. Annlas of Biological Research, 2(3), 374-379

Ali, S.K., and Saleh, A.M. (2012). Spirulina - an overviw. International Journal of Pharmacy and Pharmaceutical Sciences, 4 (3), 9-15.

Bachtiar, Y. Ir. 2006. Panduan Lengkap Budi Daya lele Dumbo. Ed ke-1. Jakarta : AgroMedia Pustaka. Halaman 4.

Belay, A. (2002). The potential application of Spirulina (Arthrospira) as a nutritional and therapeutic supplement in health management. The Journal of the American Nutraceutical Association, 5(2), 27-31. 
Beresto, V., 2001. Our experience in Spirulina feeding to minks in the reproduction period. Scientifur 25, 11-15.

Bermejo, P., Pinero E and M. A. (2008). Iron-chelating ability and antioxidant properties of phycocyanin isolated from a protein extract of Spirulina platensis. Food Chemistry 110. 436-445.

Christwardana, M,M.M.A. Nur, Hadiyanto. Review $S$. plastensis: Potensinya Sebagai Bahan Pangan Fungsional. Vol.2 No.1. Jurnal Aplikasi Teknologi Pangan.

Carrieri, D., Momot D., Brasg, I.A., Ananyev, G., Lenz, O., ryant, D.A. Dismukes, G.C. 2010. Boosting auntofermentation rates and product yields with sodium stress cycling: Application to production of renewable fuels by cyanobacteria. Journal Applied and Environmental Microbiology. 76 (19): 64555 6462

Darseno, 2013. Budidaya Lele. Ed ke-1. Jakarta : PT. AgroMedia Pustaka. Halaman 13, 14.

Demir, B.S., and Tukel, S.S. (2010). Purification and characterization of lipase from Spirulina platensis. Journal of Molecular Catalysis B: Enzymatic, 64, 123-128.

Dernekbasi, S., Una, H., Karayuccel, I., \& Aral, O. (2010). Effect of dietary supplementation of different rates of Spirulina (Spirulina platensis) on growth, and feed conversation in guppy (Poecilia reticulate peters, 1860). Journal of Animal Veterinary Advances, 9 (9), 1395 - 1399.

Ditjen Perikanan Budidaya. 2010. Bogor Sentra Budidaya Lele. http://www.perikananbudidaya.kkp.go.id/index.php ?option $=\mathrm{com}$ content $\&$ view $=$ article $\& i d=80$ : bogor-sentra-budidayalele\&catid=57:berita. (Diakses tanggal 4 Januari 2018).

Effendie, I. 2002. Biologi Perikanan. Yayasan Pustaka Nusatama. Yogyakarta.

Effendi, Irzal. 2004. Pengantar Akuakultur. Penebar Swadaya : Jakarta.

Fatimah, Nur E. dan Mada S. 2015. Budi Daya Ikan Lele dari Pembenihan, Panen raya, hingga Pasca Panen. Ed ke-1. Jakarta : Bibit Publisher

Gunawan, RGB dan Bagus H. 2011. Dongkrak Produksi Lele dengan Probiotik Organik. Ed ke-1. Jakarta : PT. AgroMedia Pustaka. Halaman : 24

Gunawan, S. 2016. Panduan Komplet Budi Daya Lele di Lahan Sempit. Jakarta : PT.AgroMedia Pustaka Gusrina. 2008. Budidaya Ikan Jilid 2 . Klaten : PT. Macan Jaya Cemerlang 
Henrikson R. 2009. Earth Food Spirulina: How this remarkable blue-green algae can transform your health and our planet. Hawaii: Ronore Enterprises.

Hernowo, R.S. 2010. Pembenihan dan Pembesaran Lele. Penebar Swadaya

Herry, 2008. Pengenalan Bahan Baku Ikan BBPBAT : Sukabumi

Hirahashi T., Matsumoto M., Hazeki K., Saeki Y., Ui M. \& Seya T. (2002). Activation of the human innate immune system by Spirulina : augmentation of interferon production and NK cytotoxicity by oral administration of hot water extract of Spirulina platensis. International Immunopharmacology 2, 423 $-434$.

Hu C, Lin J-T., Lu E-J., Chou E-P and Yang D-J. (2008). Determination of carotenoids in Dunaliella salina cultivated in taiwan and antioxidant capacity of the algal carotenoids extract. Food Chemistry 109, 439-446.

Kordi, M. G. H. 2010. A to Z Budidaya Biota Akuatik untuk Pangan,. Kosmetik, dan ObatObatan.

Kordi, M. G. H. 2010. Budi Daya Perairan Buku Kedua. Citra Aditya
Mahyudin, K. S.Pi., MM. 2008. Panduan Lengkap Agribisnis Lele + CD. Ed ke-1. Penebar Swadaya

Maryono dan A. Sundana. 2002. Teknik Pencegahan dan Pengobatan Penyakit Bercak Merah Pada Ikan Air Tawar yang Disebabkan Oleh Bakteri Aeromonas hydrophila. Buletin Teknik Pertanian., 7(1): 33-36.

Muchlisin, Z. A., A. Damhoeri, R. Fauziah, Muhammadar dan M. Musman. 2003. Pengaruh Beberapa Jenis Pakan Alami Terhadap Pertumbuhan dan Kelulushidupan Larva Ikan Lele Dumbo (Clarias gariepinus). Jurnal Biologi Vol 3(2) : $105-113$.

Nakono, T., Yamaguchi, T., Sato, M., \& Iwama, G. K. (2003). Biological Effects of Carotenoids in Fish (pp. 115). International Seminar "Effective Utilization of Marine Food Resource", Songkhala, Thailand, 18 December 2003.

Notoatmodjo, S. 2012. Metodologi Penelitian Kesehatan. Jakarta : PT Rineka Cipta

Penulis CMK, Dian A. S, Prasetya B. W. 2016. Panduan Praktis Pakan Ikan Lele. Jakarta : Penebar Swadaya..

Sahara, R. 2017. Efisiensi Pemanfaatan Pakan dan Pertumbuhan Benih Ikan Lele (Clarias sp.) dengan 
Penambahan Tepung Alga Coklat (Sargassum sp.) dalam Pakan. Jurnal Sains Teknologi Akuakultur (1) : 38-44.

Saranraj, P., \& Sivasakthi, S (2014). S. plastensis- Food for future: A Review. Asian Journal of Pharmaceutical Science andd Technology, 4 (1), 26-33.

Simanjuntak, S.B.I., Dana, D., Wirawidjaja, A.M., \& Supriyadi, H. (2002). The effectiveness of Spirulina as immunostimulants on patin jambal fish (Pangasius djambal Bleeker). Journal Biologi Indonesia, III(3), 209218 (in Indonesian).
Simanjuntak, Ida B., Indarwan, Eko S. W. 2018. Impact of Fed Containing Different Levels of Diets Supplementation Spirulina platensis on Growth, Haematological, Body Composition and Biochemical Parameters, of Gurami (Osphronemus gouramy). Turkish Journal of Fisheries and Aquatic Sciences. 18:681-690. 